\title{
Students' Reading Interest, Information Literacy, and Student Critical Thinking on Student Ability in Economic Lessons
}

\author{
Suryaman Putra ${ }^{1}$, Marwan $^{2}$, Sany Dwita ${ }^{3}$ \\ 1Universitas Negeri Padang, Padang, Indonesia, $\square$ putra.suryaman@yahoo.co.id \\ 2Universitas Negeri Padang, Padang, Indonesia, $₫$ marwan.unppdg@yahoo.co.id \\ ${ }^{3}$ Universitas Negeri Padang, Padang, Indonesia, $\square$ sanydwita@gmail.com
}

\begin{abstract}
This study aims to analyze the effect of reading interest, information literacy and students' critical thinking on student ability in economic lessons class X and XI students at Semen Padang High School. This type of research is Descriptive Associative with a population of all students of class X and XI of Semen Padang High School totaling 127 people. Sampling uses random sampling technique, the results of this sampling technique selected 96 Semen Padang high school students. The data collection tool is to use the questionnaire interest in reading, information literacy and student critical thinking instruments. The data is analyzed descriptively and inductively through path analysis "Path Analysis". And the results of the analysis can be concluded that: (1) Reading interest significantly influences Critical Thinking. (2) Information Literacy has a significant effect on Critical Thinking. (3) Reading Interest significantly ability in economic lessons. (4) Information Literacy has a significant ability in economic lessons. (5) Critical Thinking has a significant ability in economic lessons.
\end{abstract}

Keywords: reading interest, information literacy, critical thinking, ability in economic lessons

\section{Introduction}

A nation can be regarded as a quality nation if it has the potential of resources both natural resources and human resources. The quality of human resources can be seen from its education, for that we need an increase in an education system in order to increase human resources. Education is a human effort in order to develop their potential, among others through the learning process at school. Schools play a role in improving the quality of education to produce quality graduates as well.

Learning is something that is very closely related to the absorption of students, it can even be said to be the same, this can be proved by examining the statements of several education experts. (Miftahul \& Nganjuk, 2015) Absorption is a benchmark to determine the extent to which students understand the subjects taught by a teacher in the process of teaching and learning activities. This understanding is largely influenced by factors such as the interest of students in learning, a comfortable or conducive environment, and teachers who can be close friends with their students.

Based on one of the efforts in the field of education that can be done to print quality human resources, namely by getting used to forming a culture of critical thinking in students in the learning process. According to (Nuryanti, Zubaidah, \& Diantoro, 2018) A critical thinker is able to analyze and evaluate every information he receives. Critical thinking is the ability to think reflective that focuses on the pattern of decision making about what must be believed and must be done. The school must teach the right way of thinking in children, think in a higher level both critical thinking and creative thinking.

Students must also have the ability to access and evaluate information effectively to solve problems and make decisions. (Shing \& Ling, 2005) states that teaching is an action that aims to bring change in terms of trust, value and meaning. (Shing \& Ling, 2005) also states that teaching is an intellectual activity, it involves thoughts, feelings and judgments, and interactions between teachers and students and between students and students. And with learning they also master knowledge, skills, behavior, formation of attitudes, beliefs and learning processes that apply throughout life to a human. 
A solid foundation for information literacy is the reading culture of the people, currently reading interest is still an unresolved homework for the Indonesian people. According to (Triatma, 2016) states that reading interest is a desire accompanied by the efforts of someone to read, where people who have a strong interest in reading will be realized to get reading material as they wish. To realize a nation of reading culture, this nation needs to foster children's reading interest. Fostering children's reading interest is a first step as well as an effective way towards a cultured nation to read.

From the preliminary observations on November 10, 2017 in class X and XI Social Sciences (IPS) of Semen Padang High School, there were 32 students who had economic subjects below the KKM. Can be seen in the table below:

Based on observations and experiences during the preliminary survey it is suspected that there is still a lack of students' interest in reading which causes students not to understand the subjects being studied, students tend to wait for information from the teacher to find out information about the subjects being studied. which is only limited to information from educators.

From the background above the researcher was interested in conducting a study on "The Effects of Reading Interest, Information Literacy and Students' Critical Thinking Ability on the students ability in economic lessons of Class X and XI Students of Semen Padang High School".

\section{Methods}

This study uses a type of quantitative research, namely the type of research that emphasizes testing theoretical theory through the measurement of research variable variables with numbers and requires data analysis with statistical procedures. The measurement tool of this research is a questionnaire, data obtained in the form of answers from students to the questions asked .

This research was conducted at Semen Padang High School. The population in this study were all students of class X and XI Social Sciences Department of Semen Padang High School 2017/2018 Academic Year with a population of 127 students, the number of samples required was 96.3 . To be more effective rounded to 96.

In this study the author uses data collection techniques using a questionnaire or questionnaire for free variables. In this study the authors distributed questionnaires related to the influence of reading interest, information literacy and students 'critical thinking abilities while on the students ability in economic lessons on economics in the class XI students of Semen Padang High School researchers took from student report cards. The questionnaire or questionnaire was used in this study arranged using a Likert scale. Where respondents only choose one of the five alternative answers provided.

Based on the results of the analysis of the trial data on 35 students, validity and reliability of items of interest in reading, critical thinking and information literacy were obtained, with 37 items. This result is obtained by using SPSS version 16.0 by using the calculation of the value of Corrected Item-Total Corelation for validity and Cronbach Coefficient Alpha to measure reliability, all invalid items (below 0.333 ) are discarded.

\section{Results and Discussion}

\section{Analysis of Research Variable Descriptions}

Presentation of data for each variable in the form of frequency distribution, where each respondent gave an assessment in accordance with their opinions. To describe 37 statements consisting of 15 items for reading interest variables (X1), 12 statements for information literacy variables (X2), 10 statements for critical thinking variables (X3). Where the points of these statements have met the validity and reliability test. 


\section{Students Ability in Economic Lessons (Y)}

From the data received from Semen Padang High School, grade X and XI IPS the highest score on economics is 95 in class X IIS II and the lowest score on economic subjects in class X IIS I is 58. In the table below can be seen the interval of students ability in economic lessons Semen Padang high school students on economics.

Table 1 Value of Student Learning Outcomes (Respondents)

\begin{tabular}{ccc}
\hline Class Interval & Frequency & \% \\
\hline $58-62$ & 1 & 1,04 \\
\hline $63-67$ & 4 & 4,17 \\
\hline $68-72$ & 7 & 7,29 \\
\hline $73-77$ & 20 & 20,84 \\
\hline $78-82$ & 32 & 33,34 \\
\hline $83-87$ & 26 & 27,08 \\
\hline $88-92$ & 4 & 4,16 \\
\hline $93-97$ & 2 & 2,08 \\
\hline Total & 96 & 100 \\
\hline Average & $\mathbf{7 9 , 7 7}$ \\
\hline Median & $\mathbf{8 0}$ \\
\hline Mode & $\mathbf{7 7 , 7}$ \\
\hline Standard Deviation & $\mathbf{6 , 4 3}$ \\
\hline Maksimum & 95 \\
\hline Minimum & 58 \\
\hline
\end{tabular}

Based on the table above, it can be seen that the highest student scores are in the range of 78-82 by $33.34 \%$ and the value of the students at least in the range of $58-62$ is $1.04 \%$, it can be concluded that 32 students or $33.3 \%$ students do not meet the KKM value of 78 .

\section{Reading interest}

Data on students' interest in reading in this study was obtained through a questionnaire (questionnaire) distributed to 96 respondents with 15 points of statement to class X students, XI IPS Semen Padang High School. The research data obtained can be seen in the table below:

Table 2 Frequency Distribution of Reading Interest

\begin{tabular}{llcccc}
\hline No & \multicolumn{1}{c}{ Indicator } & $\begin{array}{c}\text { No of } \\
\text { Item }\end{array}$ & Mean & $\begin{array}{c}\text { TCR } \\
(\mathbf{\%})\end{array}$ & Criteria \\
\hline 1 & Feeling happy to Read & 5 & 4.7 & 90.6 & Very good \\
\hline 2 & The need for reading books & 5 & 4.8 & 92.7 & Very good \\
\hline 3 & The desire to read & 5 & 4.4 & 88.8 & Well \\
\hline Variable average & & 4.6 & 90.7 & Very good \\
\hline
\end{tabular}

Based on the table, it can be seen that students' interest in reading has an average level of achievement of respondents of $90.7 \%$ with a mean score of 4.6 in the excellent category. On the first indicator, namely the feeling of pleasure in reading has the highest average of 4.7 TCR of $90.6 \%$ and the need for reading 
4.8, the TCR of $92.7 \%$ is very good. This means that the reading interest of class X and XI IPS students at Semen Padang High School is very good because of the sufficient library facilities at Semen Padang High School where the school complements all the needs of textbooks and other supporting books in the library. Despite the desire to read the level of respondent's achievement 88.8 which is at a good level, this can be seen from the completeness of the adequate library at Semen Padang High School.

\section{Information Literacy}

Data on information literacy in this study was obtained through a questionnaire (questionnaire) distributed to 96 respondents with 12 items of statements to class X students, XI IPS Semen Padang High School. The research data obtained can be seen in the table below:

Table 3 Information Literacy Frequency Distribution

\begin{tabular}{clcccc}
\hline No & indicator & $\begin{array}{c}\text { No } \\
\text { of } \\
\text { Item }\end{array}$ & Mean & $\begin{array}{c}\text { TCR } \\
\mathbf{( \% )}\end{array}$ & criteria \\
\hline 1 & Formulating Problems & 2 & 4.4 & 88.7 & well \\
\hline 2 & Try to solve the problem & 2 & 4.5 & 91.5 & Very good \\
\hline 3 & Presenting Information & 2 & 4.4 & 92.3 & Very good \\
\hline 4 & Reasoning & 3 & 4.6 & 93.46 & Very good \\
\hline 5 & Creating a work & 3 & 4.7 & 94 & Very good \\
\hline & Variable average & 12 & 4.5 & 91.8 & Very good \\
\hline
\end{tabular}

Based on the table, it can be seen that information literacy has an average level of achievement of respondents $91.8 \%$ with a mean score of 4.5 with TCR $91.8 \%$ in the very good category. In the first indicator which is at a good level which has a mean of 4.4 and TCR of $88.7 \%$ and the highest average in the fifth indicator where the average is 4.7 and TCR is $94 \%$ it can be concluded that Semen Padang high school students can use information literacy with well. All of this is evidenced by the existence of a complete library per school even though one elementary, middle and high school environment but each school has a library and internet network in accessing information.

\section{Critical thinking}

Critical thinking data in this study was obtained through a questionnaire (questionnaire) distributed to 96 respondents with 10 items of statement to class X students, XI IPS Semen Padang High School. The research data obtained can be seen in the table below:

Table 4 Frequency Distribution of Critical Thinking

\begin{tabular}{llcccl}
\hline No & \multicolumn{1}{c}{ Indicator } & $\begin{array}{c}\text { No } \\
\text { of Item }\end{array}$ & Mean & $\begin{array}{c}\text { TCR } \\
(\mathbf{\%})\end{array}$ & Criteria \\
\hline 1 & Give a simple explanation & 3 & 4.4 & 89.4 & Well \\
\hline 2 & Build basic skills & 2 & 4.6 & 92.9 & Very good \\
\hline 3 & Conclude & 2 & 4.7 & 93.1 & Very good \\
\hline 4 & $\begin{array}{l}\text { Provide further } \\
\text { explanation }\end{array}$ & 2 & 4.5 & 90.9 & Very good \\
\hline 5 & Set strategy and tactics & 1 & 4.3 & 87.2 & Well \\
\hline Variable average & 10 & 4.4 & 90.7 & Very good \\
\hline
\end{tabular}

Based on the table it can be seen that critical thinking has an average level of achievement of respondents $90.7 \%$ with a mean score of 4.4 in the excellent category. On the first and fifth indicators which are at a good level which have a mean of 4.4 and 4.3 and TCR of $89.4 \%$ and 87.2 . The highest 
average on the third indicator where the average owned is 4.7 and TCR is 93.1. Students of Semen Padang High School have the characteristics and critical talents who have high imaginative curiosity and always respect the rights of others, direction and guidance of others. It can be concluded that Semen Semen high school students think critically in school learning.

\section{Discussion}

By considering and looking at the exposure to the results of the research in the previous section, the authors can present the discussion from the research as follows:

\section{Effect of Reading Interest (X1) Against Critical Thinking (X3) Students of Class X And XI IPS Semen Padang High School}

Based on the testing of hypotheses obtained the coefficient value of the direct influence of reading interest on critical thinking is equal to $3.84 \%$ with a significance level of 0.033 . This shows that there is a significant influence on reading interest variables towards critical thinking. In this case critical thinking is formed from reading interest carried out by students at Semen Padang High School.

Based on the results of variable descriptions it is known that reading interest has good criteria, this can be seen from the average score of 4.6 with $88.8 \%$ TCR. This means that reading interest is sufficient. According to (Triatma, 2016) people who have strong reading interest will manifest it in their willingness to get reading material and then read it on their own awareness. Reading material includes newspapers, magazines, textbooks, knowledge books outside of textbooks, and story books.

To increase reading interest there are so many ways that students can do such as often going to the library to be able to find a lot of information and can increase knowledge. So that students' thinking skills increase and teachers should provide assignments that can be analyzed by students, with the task students can generate reading interest and critical thinking.

\section{Effect of Information Literacy (X2) on Critical Thinking (X3) Students of Class X And XI IPS Semen Padang High School}

Based on the testing of hypotheses obtained the coefficient value of direct influence of information literacy on critical thinking is equal to $18.31 \%$ with a significance level of 0,000 . This shows that there is a significant influence on Information literacy variables towards critical thinking. In this case critical thinking is formed from Information literacy carried out by Semen Padang High School students. Based on the results of the variable description, it is known that Information literacy has good criteria, this can be seen from the average score of 4.5 with TCR of $91.8 \%$, which means that information literacy in Semen Padang High School is very adequate.

(Septiyantono, 2012) states that information literacy is an ability to access, evaluate, organize, and use information in the learning process, problem solving, making formal and informal decisions in the context of learning, homework, or even in education. Someone who has information literacy is someone who knows how to learn to learn because they usually know how information is managed, how to find, and use information in accordance with applicable ethics. With the ability of students to manage and access information with applicable ethics, students can increase their absorption or learning outcomes, in Semen Padang High School students can easily search information and access information because it is equipped with a library and internet access.

\section{Influence of Reading Interest (X1) Students Ability In Economic Lessons (Y) in Class X and XI Students of Semen Padang High School}

Based on the testing of hypotheses obtained that reading interest has a significant effect on the students ability in economic lessons (Y) in class X and XI students of Semen Padang High School. Both direct reading interest in students' absorption and indirectness through critical thinking. From the results 
of the analysis, it can be seen that the direct influence of reading interest on students ability in economic lessons is $10.36 \%$ compared to indirect effects through critical thinking which is equal to $1.47 \%$. The results of the descriptive analysis showed that reading interest was in a very good category, namely at TCR of $90.7 \%$.

In accordance with the results of the study (Miftahul \& Nganjuk, 2015) The students ability in economic lessons towards subject matter will have very high potential when supported by a high interest in learning, a comfortable and conducive environment and friendly teachers. That is, students' interest in reading is high and equipped with books and other supporting reading materials so that the students ability in economic lessons will increase. To increase reading interest there are so many ways that students can do such as often going to the library to be able to find a lot of information and can increase knowledge.

By reading books and other media students get new knowledge, what else is now reading is not only focused on books but also can be done digitally with the help of technology such as digital books that can be accessed through the internet so students can read and search information easily. At SMA Semen Padang library and can be accessed easily because of the availability of complete books and convenience in reading books in the school library.

\section{Effect of Information Literacy (X2) Students Ability In Economic Lessons (Y) In Class X and XI Students of Semen Padang High School}

Based on the testing of hypotheses obtained that information literacy (X2) has a significant effect on the students ability in economic lessons (Y) in class X and XI students of Semen Padang High School. Both directly information literacy towards students ability in economic lessons and indirect through critical thinking.

From the results of the analysis, it can be seen that the direct effect of information literacy on the students ability in economic lessons has a greater influence, which is equal to $24.20 \%$ compared to indirect effects through critical thinking, which is equal to $2.24 \%$. The results of the descriptive analysis show that information literacy is in a very good category, that is, at TCR of $91.8 \%$. While critical thinking is in the very good category too, which is equal to TCR of $90.7 \%$.

With the ability to access and use technology in finding information about things to be learned or who want to be known to improve student learning outcomes. In Semen Padang High School information seeking students is very good because it is equipped with support such as libraries and internet by schools, with the aim of facilitating the search for information students can increase their students ability in economic lessons and learning outcomes.

In accordance with the results of the study (Professionals, 2009) this information literacy ability serves to challenge and motivate students to improve their rankings in the future, reflective assessment of information literacy can play an important role in involving students with resolved concepts, they have the opportunity to develop broader awareness information environment.

\section{Effect of Critical Thinking (X3) Students Ability in Economic Lessons (Y) in Class X and XI Students of Semen Padang High School}

Based on the hypothesis testing obtained that critical thinking has a significant effect on the students ability in economic lessons (Y) in class X and XI students of Semen Padang High School. Critical thinking as an intervening variable does not have an indirect influence on students ability in economic lessons. From the results of the analysis, it can be seen that the direct effect of thinking critically on students ability in economic lessons is $5.42 \%$. Based on the results of the variable description it is known that critical thinking has very good criteria, this can be seen from the average score of 4.4 with TCR $90.7 \%$.

From the explanation, it can be concluded that in order to get excellent students ability in economic lessons of students at Semen Padang High School, students must have a high reading interest because 
reading will increase their knowledge. Not just reading by accessing information well and positively will also increase students ability in economic lessons, high reading interest and good information literacy will create students' critical thinking, because students will manage everything they can by thinking of better students ability in economic lessons.

In accordance with research (Lunenburg, 2011) all students will demonstrate competency on subject challenges in the core subject areas of reading, mathematics, science, social studies, and learning to use their minds well. Critical thinking and constructivism offer real promises to improve the achievement of all students in the core field of study.

\section{Conclusions}

Based on the results of research and discussion, conclusions can be taken as Reading interest has an influence on students' critical thinking. The form of the influence of the reading interest variable on critical thinking is positive. This shows, with the reading interest, critical thinking of students will increase. Information Literacy has an influence on students' critical thinking. The form of the influence of Information literacy variables on students' critical thinking is positive. This shows, with the existence of Information literacy, students' critical thinking will increase. Reading interest has an influence on student absorption. The form of the variable interest in Reading Interest on student absorption is positive. This shows that with Reading Interest, student absorption will increase. The more and complete books and reading materials of students, the better students ability in economic lessons will be. Information Literacy has an influence on student absorption. The form of the influence of information literacy variables on student absorption is positive. This shows that with Information Literacy, students ability in economic lessons will increase. The more and complete information literacy, the better students ability in economic lessons will be. Critical thinking has an influence on students ability in economic lessons. The form of the influence of critical thinking variables on students ability in economic lessons is positive. This shows that critical thinking is needed for maximum students ability in economic lessons. With good critical thinking can increase students ability in economic lessons.

\section{References}

Lunenburg, F. C. (2011). Critical Thinking and Constructivism Techniques for Improving Student Achievement, 21(3), 1-9.

Miftahul, N. S., \& Nganjuk, U. K. (2015). Potensi Daya Serap Anak Didik Terhadap Pelajaran. Potensi Daya Serap Anak Didik Terhadap Pelajaran Diterima, 1(September). Retrieved from http://ejournal.kopertais4.or.id/mataraman/index.php/lentera/article/view/1259

Nuryanti, L., Zubaidah, S., \& Diantoro, M. (2018). Analisis Kemampuan Berpikir Kritis Siswa SMP, (2006), 155-158.

Professionals, I. (2009). Integrating information literacy as a habit of learning - assessing the impact of a thread of IL through the curriculum, 3(1).

Septiyantono, T. (2012). Konsep Dasar Literasi Informasi. Pust4314/Modul 1. Retrieved from http://www.pustaka.ut.ac.id/lib/wp-content/uploads/pdfmk/PUST4314-M1.pdf

Shing, ting kung, \& Ling, woo yoke. (2005). Fakulti Pendidikan Universiti Teknologi Malaysia Subtema: ICT Dalam Pendidkan Guru. Seminar Pendidikan 2005, 1-17.

Triatma, I. N. (2016). Minat Baca Pada Siswa Kelas VI Sekolah Dasar Negeri Delegan. E-Jurnal Prodi Teknologi Pendidikan, V Nomor 6(Teknologi Pendidikan), 166-178. 